\title{
DEVELOPMENT OF A BITTER MELON BASED SUPPLEMENTARY CAPSULE
}

BY

PANADURA ARACHCHIGE NADI GAYANI PERERA

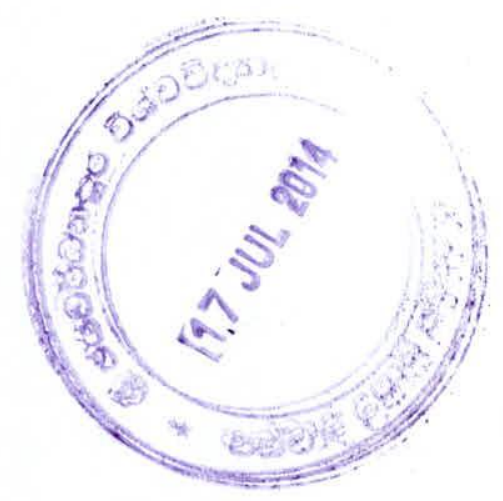

Thesis submitted in partial fulfilment of the requirement for the Degree of Master of Food Science and Technology, Department of Food Science and Technology, Faculty of Applied Sciences, University of Sri

Jayewardenepura, Nugegoda, Sri Lanka. 


\section{DECLARATION}

The work described in this project was carried out by me at the University of Sri Jayawardenepura, under the supervision of Prof. K. K. D. S. Ranaweera, Department of Food Science and Technology, University of Sri Jayawardenepura; Director, Bandaranaike Memorial Ayurvedic Research Institute, Nawinna, Maharagama; and this thesis has not been submitted in whole or in part of any University or any other institution for another Degree/ Diploma.

$22103 / 2014$

Date

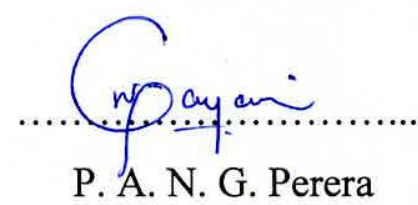

P. A. N. G. Perera 
I certify that the above statement made by the candidate is true and that this thesis is suitable for submission to the University of Sri Jayawardenepura for the purpose of evaluation.

\section{Supervisor:}

Prof. (Mr.) K. K. D. S. Ranaweera

Department of Food Science and Technology,

Faculty of Applied Sciences,

University of Sri Jayewardenepura,

Nugegoda,

Sri Lanka.

Director,

Bandaranaike Memorial Ayurvedic Research Institute,

Nawinna,

Maharagama,

Sri Lanka 
Dedicated to my beloved mother, father and brother for their eternal love and support. 


\section{Table of content}

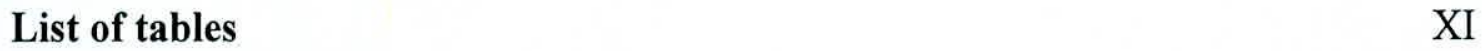

List of figures $\quad$ XII

$\begin{array}{ll}\text { Abbreviations } & \text { XIII }\end{array}$

$\begin{array}{ll}\text { Acknowledgement } & \text { XIV }\end{array}$

$\begin{array}{ll}\text { Abstract } & \text { XV }\end{array}$

Chapter 1 - Introduction 1

Chapter 2 - Literature review 3

2.1 Dietary supplements 3

2.2 Bitter melon/ Bitter gourd/ Bitter squash/ Momordica charantia Linn $\quad 4$

2.2.1 Botanical description of Momordica charantia 4

2.2.2 General appearance $\quad 5$

2.2.3 Origin and distribution 5

$\begin{array}{lc}2.2 .4 \text { Varieties } & 6\end{array}$

$\begin{array}{ll}\text { 2.2.5 Properties according to Ayurveda } & 6\end{array}$

$\begin{array}{lr}\text { 2.2.6 Contraindications } & 6\end{array}$

$\begin{array}{ll}\text { 2.2.7 Side effects and toxicity } & 7\end{array}$

$\begin{array}{ll}\text { 2.2.8 Interactions with other drugs } & 8\end{array}$

2.2.9 Nutritional aspect of Momordica charantia 9

2.2.10 Momordica charantia as a functional food $\quad 11$

$\begin{array}{ll}\text { 2.2.11 Major chemical constituents/ Phytochemicals } & 11\end{array}$

2.2.11.1 Flavonoids 12

$\begin{array}{ll}\text { 2.2.11.2 Alkaloids } & 14\end{array}$ 
2.2.11.4 Saponins

2.2.11.5 Glycosides

2.2.11.6 Phenols

2.2.11.7 Steroids

2.2.11.8 Terpenoids

2.2.11.9 Proteins

2.2.16. 1 Antidiabetic activity 22

2.2.16. 2 Normalization activity of the hypertension 23

2.2.16. 3 Stomachic activity 24

2.2.16. 4 Liver and biliary aiding activity 24

2.2.16. 5 Anti leprotic and anti psoriatic activity 24

2.2.16. 6 Anti cancerous and anti tumorous activity 25

2.2.16. 7 Activity of anti obesity 25

2.2.16. 8 Anti microbial activity $\quad 26$

2.2.16. 9 Anti oxidative activity 26

$\begin{array}{ll}2.2 .16 .10 \text { Anti viral activity } & 27\end{array}$

2.2.16.11 Anti HIV agent 27 
2.2.16.14 Anti-genotoxic activity

2.2.16.15 Anti-helmintic activity

2.2.16.16 Anti-malarial activity

2.2.16.17 Anti-neoplastic activity

2.2.16.18 Anti ulcerative and immuno modulatory activity

2.3 Encapsulation and capsule dosage forms

2.4 Inductively Coupled Plasma - Optical Emission Spectroscopy (ICP/ OES)

2.5 Assay of Alpha Amylase inhibitory activity to detect the hypoglycemic activity33

Chapter 3 - Experimental methods

3.1 Development of the bitter melon based capsule

3.1.1 Identification of Momordica charantia (Bitter melon) and Collection of the fruits/ pods

3.1.2 Preparation and selection of dried bitter melon powder

3.1.3 Determination of the dose of capsules

3.1.4 Determination of the needed liquid extract of bitter melon fruits

3.1.5 Preparation of bitter melon aqueous extract

3.1.6 Formulation of bitter melon based capsules 
3.2.6.1 Determination of Reducing Sugar 45

3.2.6.1.1 Standardization of Fehling solution 45

3.2.6.2. Determination of Total Sugar 46

3.2.7 Determination of vitamin C $\quad 46$

3.2.7.1 Standardization of indophenols dye solution 47

3.2.7.2 Determination of ascorbic acid in Bitter melon sample 47

3.2.8 Determination of Mineral content using Inductively Coupled

$\begin{array}{ll}\text { Plasma Spectrometer (ICP-OES) } & 47\end{array}$

3.2.8.1 Sample Preparation - Microwave Digestion 47

3.2.8.2 Measurement of Metals Using ICP-OES 48

3.3 Determination of microbial activity $\quad 49$

3.3.1 Determination of total plate count 49

3.3.2 Determination of yeast and moulds $\quad 51$

3.3.3 Determination of coliform count 51

3.3.3.1 Examination of presumptive coliforms $\quad 51$

3.3.3.2 Examination of faecal coliforms $\quad 52$

3.4 Determination of medicinal value 53

3.4.1 Preparation of extracts $\quad 53$

$\begin{array}{ll}\text { 3.4.2 Phytochemical analysis } & 54\end{array}$

3.4.2.1 Flavonoids $\quad 54$ 
3.4.2.5 Glycosides $\quad 56$

$\begin{array}{ll}\text { 3.4.2.6 Phenols } & 57\end{array}$

$\begin{array}{ll}\text { 3.4.2.7 Steroids } & 57\end{array}$

$\begin{array}{ll}\text { 3.4.2.8 Terpenoids } & 58\end{array}$

$\begin{array}{ll}\text { 3.5 Assay of alpha amylase inhibitory activity } & 58\end{array}$

$\begin{array}{ll}\text { Chapter 4 - Results and Discussion } & 60\end{array}$

4.1 Development of the bitter melon based capsule $\quad 60$

4.1.1 Identification of Momordica charantia (Bitter melon) and Collection

of the fruits/ pods $\quad 60$

4.1.2 Preparation and selection of dried bitter melon powder 61

4.1.3 Determination of the dose of capsules 63

4.1.4 Determination of the needed liquid extract of bitter melon fruits 63

4.1.5 Preparation of bitter melon aqueous extract 64

4.1.6 Formulation of bitter melon based capsules $\quad 65$

4.2 Determination of Nutritional Value 66

4.2.1 Determination of moisture $\quad 66$

$\begin{array}{ll}\text { 4.2.2 Determination of total ash } & 67\end{array}$

$\begin{array}{ll}\text { 4.2.3 Determination of crude fiber } & 67\end{array}$

$\begin{array}{ll}\text { 4.2.4 Determination of crude protein } & 68\end{array}$

4.2.5 Determination of total fat $\quad 69$ 
4.2.8 Determination of Mineral content using Inductively Coupled

Plasma Spectrometer (ICP-OES)

4.3 Determination of microbial activity

4.3.1 Determination of total plate count

4.3.2 Determination of yeast and moulds

4.3.3 Determination of coliform count

4.4 Determination of medicinal value

4.5 Assay of alpha amylase inhibitory activity

Chapter 5 - Conclusions

Chapter 6 - Suggestions and recommendations

References

$84-91$ 


\section{List of tables}

Table 1 Bitter gourd or bitter melon (Momordica charantia), fresh, raw, nutritive value per $100 \mathrm{~g}$ nutritional composition

Table 2 Moisture content of two varieties of M. charantia fruits at different temperatures

Table 3 Moisture content of the samples of dried powder and extract mixture 66

Table 4 Ash content of the samples of dried powder and extract mixture

Table 5 Crude fiber content of the samples of dried powder and extract mixture 67

Table 6 Crude protein content of the samples of dried powder and extract mixture

Table 7 Total fat content of the samples of dried powder and extract mixture

Table 8 Reducing sugar and total sugar of the samples of dried powder and extract mixture

Table 9 Total plate count of the samples of dried powder and extract mixture

Table 10 Yeast and moulds of the samples of dried powder and extract mixture 75

Table 11 Coliform count of the samples of dried powder and extract mixture $\quad 76$

Table 12 Phytochemical analysis of Momordica charantia Fruit

Table 13 Reducing sugar content in solution A and B 


\section{List of Figures}

Figure 1 Matured bitter melon fruits/ pods

Figure 2 Molecular structure of the flavone backbone

(2-phenyl-1, 4-benzopyrone)

Figure 3 Isoflavan structure

Figure 4 Neo flavonoids structure

Figure 5 Structure of momordicin

Figure 6 Structure of catechin

Figure 7 Structure of a saponin

Figure 8 Structure of charantin

Figure 9 Structure of a hard gel capsule

Figure 10 Structure of an ICP-OES

Figure 11 Structure of an ICP

Figure 12 Flow diagram for the preparation of dried bitter melon powder

Figure 13 Flow diagram for the preparation of bitter melon aqueous extract

Figure 14 Fruits of triangular type variety

Figure 15 Fruits of small/ short type variety

Figure 16 Moisture variation with drying temperature

Figure 17 Bitter melon fruit powder of triangular type variety dried at $50^{\circ} \mathrm{C}$

Figure 18 Bitter melon aqueous extract

Figure 19 Prepared bitter melon capsules

Figure 20 Proximate analysis of the product 


\section{Abbreviations}

CAM

DSHEA

FDA

GMP

IUPAC

ROS

HIV

USDA

AMPK

DM

LDL

CLnA

MAP30

AIDS

SMS

WHO

AOAC

AHPA

ICP
Complementary and Alternative Medicine

The Dietary Supplement Health and Education Act

Food and Drug Administration

Good Manufacturing Practices

International Union of Pure and Applied Chemistry

Reactive Oxygen Species

Human Immunodeficiency Virus

United States Department of Agriculture

Adenosine 5 Mono Phosphate Kinase

Diabetes Mellitus

Low Density Lipo-protein

Conjugated Linolenic Acid

Momordica Anti-human Immuno virus Protein

Acquired Immuno Deficiency Syndrome

Sodium Meta-bi Sulphate

World Health Organization

Association of Analytical Communities

American Herbal Product Association

Inductively Coupled Plasma 


\section{ACKNOWLEDGEMENT}

First and foremost I wish to express my sincere gratitude to my supervisor professor K. K. D. S. Ranaweera, Department of Food Science and Technology, University of Sri Jayewardenepura, Nugegoda; Director of Bandaranaike Memorial Ayurvedic Research Institute, Nawinna, Maharagama; for his excellent advices, guidance, valuable suggestions, support and contribution throughout my research project.

I would like to extend my gratitude to Dr. Jagath Wansapala, Co-ordinator of the M.Sc. Food Science and Technology Programme, Mrs. Rupika Perera, Assistant Co-ordinator of the M.Sc. Food Science and Technology Programme and the academic staff of the M.Sc. Food Science and Technology Programme, University of Sri Jayewardenepura, Nugegoda, for their advices, co-ordination and support throughout the research project.

I would like to express my thanks to the technical staff of the Department of Food Science and Technology, University of Sri Jayewardenepura, Nugegoda, for their technical assistance. My sincere thank goes to Mr. Rupasingha for his valuable support during all the laboratory works.

I'm also grateful to all of my colleagues who followed the M.Sc. course with me, especially Mr. Randika Dasanayake, Mr. Nishan Perera, Mr. Nalin Ariyarathne, Mrs. Dhammika Dharmarathne, Ms. Theekshani Liyanage, Ms. Waruni Samarasekara, Mrs. Lasantha Abenayake and Mr. Mohammed Ishan for their assistance in numerous ways to finish my project with success.

Finally my heartiest thank goes to my beloved parents and brother for their understanding, dedication, kind support and assistance throughout my entire research project. 


\title{
Development of a Bitter Melon Based Supplementary Capsule
}

\section{By: Panadura Arachchige Nadi Gayani Perera}

\begin{abstract}
Bitter Melon (Momordica charantia) fruits are consumed by mankind since centuries as a vegetable and herb. But most people are reluctant to consume it due to its undesirable taste of bitterness. The objectives of the present study were to develop a bitter melon based supplementary capsule which was in the progress of masking bitterness, to nutritionally and microbiologically analyze the finished product, to evaluate its medicinal value and to evaluate the hypoglycemic activity by the assay of alpha amylase inhibitory activity.
\end{abstract}

The triangular type of $M$. charantia fruits dried at $50{ }^{\circ} \mathrm{C}$ was selected to prepare capsules. In the development of capsules, usage of only dried powder was not applicable, as the WHO recommended daily dose of dried powder ranges from $2 \mathrm{~g}-15 \mathrm{~g}$. On the other hand, despite the recommended daily dose of aqueous extract ranges from $300 \mathrm{mg}$ to $600 \mathrm{mg}$, aqueous extract alone cannot be the best presentation as it lacks fibre, minerals and some other phytochemicals. Therefore, the dried powder enriched with aqueous extract with the ratio of 7:1 (350mg: $50 \mathrm{mg}$ ) was considered as a beneficial formulation to meet the recommended daily requirement.

Hence, $1 \mathrm{~g}$ of extract was mixed with $7 \mathrm{~g}$ of dried powder to prepare capsules. Required millilitres of water extract which resembled $1 \mathrm{mg}$ of solid extract was determined according to the extraction method of Harbone, (1998). According to the results obtained, 1mg of solid extract was equivalent to $0.11 \mathrm{ml}$ of water extract of dried bitter melon powder. Therefore, needed water extract was $110 \mathrm{ml}$ to have $1 \mathrm{~g}$ of extract. A volume of $110 \mathrm{ml}$ of water extract was mixed with $7 \mathrm{~g}$ of dried powder of $M$. charantia and kept in a dryer at 50 ${ }^{\circ} \mathrm{C}$ for several days. A finished capsule was weighed approximately about $400 \mathrm{mg}$ which resembled 50mg of extract and 350mg of dried powder and the determined beneficial dose was 2 capsules three times per day.

Finished products were tested nutritionally (on dry basis) and microbiologically to assess the nutritional value and microbial quality. The developed supplementary capsule had $50.79 \%$ of carbohydrate, $28.50 \%$ of protein, $13.77 \%$ of fiber, $5.72 \%$ of fat, $7.96 \%$ of moisture, $7.03 \%$ of ash, $7.52 \%$ of reducing sugar, $9.88 \%$ of total sugar and $54 \mathrm{mg} / 100 \mathrm{~g}$ of 
vitamin C respectively. It was also found to contain $5432.4 \mathrm{mg} / 100 \mathrm{~g}$ of potassium, $698.5 \mathrm{mg} / 100 \mathrm{~g}$ of phosphorus, $474.5 \mathrm{mg} / 100 \mathrm{~g}$ of calcium, $295.9 \mathrm{mg} / 100 \mathrm{~g}$ of magnesium and $8.14 \mathrm{mg} / 100 \mathrm{~g}$ of iron in dry basis. Total energy value was $368.64 \mathrm{kcal} / 100 \mathrm{~g}$. The total plate count $\left(2.6^{*} 10^{1} \mathrm{cfu} / \mathrm{g}\right)$, Yeast and moulds $\left(7.9^{*} 10^{2} \mathrm{cfu} / \mathrm{g}\right)$ and coliforms $\left(0.2 * 10^{1}\right)$ were in the range of acceptable values according to American Herbal Products Association (AHPA). No faecal coliforms were detected in the product.

Phytochemical analysis was done qualitatively according to Harbone (1998) and Evans, (1989) to determine and compare the bioactive phyto-compounds in raw fruit and the dried powder of M. charantia by using aqueous and methanol extracts. It was revealed that the dried powder of bitter melon fruits were found to be rich with flavonoids, alkaloids, tannins, saponins, glycosides, phenols and steroids as same as the fresh fruit and accordingly it can be suggested to have potential medicinal values in it.

Supplementary capsules were subjected to the assay of alpha amylase inhibitory activity and the results obtained indicated some sort of inhibitory activity.

Hence, developing a bitter melon based supplementary capsule with higher nutritional value, medicinal value, keeping quality, cost effectiveness and lower microbial activity can be considered successful. 